\title{
Renewable energy sources in the light of regulations of the Polish law and the European Union Law
}

\author{
0dnawialne źródła energii \\ w świetle polskich \\ i unijnych regulacji prawnych
}

http://dx.doi.org/10.12775/PYEL.2014.008

\begin{abstract}
Renewable energy sources are an area which currently is raising an enormous interest of investors, state governments and international organizations. According to the strategy of the European Union, the participation of energy from renewable energy sources (RES) should be at the level of $20 \%$ by 2020 . As a result of the European Union policies aiming at reaching intended goals, it became a necessity

- Ph.D. Candidate at the Institute of Environmental Law and Science of Public Administration, Faculty of Law, University in Bialystok, Windykator Polska LLC, Białystok.

" Ph.D. Candidate at Institute of Environmental Law and Science of Public Administration, Faculty of Law, University in Bialystok, Legal advisor trainee in Białystok.
\end{abstract}




\section{Grzegorz Ignatowicz, Edyta Dołęgowska}

to adapt the existing legal systems, economic and political conditions in such a way as to not only increase the attractiveness of investing in renewable energy, but also to help to reduce greenhouse gas emissions, and thereby to improve climatic conditions.

At the moment in Poland no separate legal regulation which considers widely defined issues related to renewable energy sources is functioning. The adoption of such a regulation may lead our country closer to the European countries, where such systems already exist, as well as may adjust our legislation to the European standards. Going ahead, to fulfill the current requirements, on 8 April 2014 the Council of Ministers adopted a draft law of the Act on renewable energy sources. Entering this act into force is the final step in the implementation of the EU directives on increasing the participation of renewable energy in the total energy consumption.

Key words: Renewable energy sources; RES; implementation; support systems; certificates of origin

\section{Streszczenie}

Odnawialne źródła energii są dziedziną, która aktualnie wzbudza olbrzymie zainteresowanie inwestorów, rządów państw, a także organizacji międzynarodowych. Według strategii Unii Europejskiej udział energii pozyskiwanej z odnawialnych źródeł energii (OZE) powinien wynosić w 2020 roku 20\%. W efekcie polityki Wspólnoty zmierzającej do realizacji zamierzonych celów konieczne stało się dostosowanie istniejących systemów prawnych, warunków gospodarczych i politycznych w taki sposób, aby nie tylko zwiększyć atrakcyjność inwestowania w OZE, ale również przyczynić się do zmniejszenia emisji gazów cieplarnianych, a co za tym idzie poprawy warunków klimatycznych.

W Polsce na chwilę obecną nie funkcjonuje żadna odrębna regulacja prawna, która poruszałaby kwestie szeroko pojętej problematyki związanej z odnawialnymi źródłami energii. Przyjęcie takiej regulacji z jednej strony przybliży nasz kraj do państw europejskich, w których takie systemy już funkcjonują, a także dostosuje nasze ustawodawstwo do norm Unijnych. Idąc naprzeciw obecnym wymaganiom Rada Ministrów w dniu 8 kwietnia 2014 roku przyjęła projekt ustawy o odnawialnych źródłach energii. Wprowadzenie w życie ustawy ma być ostatnim etapem wdrożenia dyrektyw unijnych o zwiększeniu udziału energii ze źródeł odnawialnych w całkowitym zużyciu energii.

Słowa kluczowe: odnawialne źródła energii; OZE; implementacja; systemy wsparcia; świadectwa pochodzenia 


\section{Inroduction}

The increase in carbon dioxide emissions and the depletion of fossil fuels have caused an increased interest in renewable energy sources. In addition to the problem of the depletion of fossil fuel reserves, an important issue is the environmental pollution in the form of, inter alia, acid rain, ozone hole, the greenhouse effect and smog. These factors made people explore new methods of obtaining cheaper and safer energy, which would be combined with the avoidance of environmental damage, the deepening of the climate problem, and the independence of import of energy resources. They also caused the attempts to implement a new approach in the field of energy policy, namely the use of renewable energy factors in the production process.

According to data provided by the Energy Regulatory Office (ERO) for the years 2005-2013, there was a sharp increase in the use of natural energy sources. From the statistics dated on 31 March 2014 there comes a conclusion that the amount of energy generated from renewable sources and confirmed by the certificates of origin was nearly 12 billion MWh, the most of which was produced by wind power stations ${ }^{1}$. Wind power stations are currently the leader in both the number of existing installations, as well as the power of installed wind farms.

Polish accession to the European Union in 2004 somehow imposed on our country to start procedures for the implementation of techniques for getting energy from renewable sources, and reducing $\mathrm{CO} 2$ emissions into the atmosphere. The European Union policy in this area is based on imposing an obligation on Member States to increase the share of RES in the final energy consumption. In order to facilitate the achievement of this aim, Member States should adjust its legislation to the EU standards, and encourage investment in the energy sector.

Regulation proposed by the Polish Legislator guarantees reaching 15\% participation of energy from renewable sources in the final gross energy consumption in $2020^{2}$. In the light of the ongoing discussions on the final

1 Data of the Energy Regulatory Office, Ilosic energii elektrycznej wytworzonej w OZE w latach 2005-2013, potwierdzonej świadectwami pochodzenia, source: < www.ure.gov.pl> (29.06.2014).

2 Source: https://www.premier.gov.pl/wydarzenia/decyzje-rzadu/projekt-ustawy-oodnawialnych-zrodlach-energii.html (27.06.2014). 
shape of the new act it is extremely important to implement support systems for producers of electricity from renewable sources or agricultural biogas.

\section{European Union}

The energy sector in the European Union has been restructured for more than twenty years, which aim is to achieve balance between market mechanisms and legal regulation. For this purpose, acts to somehow "control" strategy of the European Union in the field of RES are created. These are the EU ordinances, directives and decisions. Strategic assumptions, including activities in a given field, as well as troubleshooting tactics are included in the so-called White Papers. They are elaborated on the basis of the Green Papers, which contain specialized studies prepared by the Commission and the EU commissioners. Green Papers influence the shaping of the EU legislation and also inspire debate in the arena of the EU Member States ${ }^{3}$.

Energy policy of the European Union was a priority objective intending to create a uniformed energy market in the frames of the uniformed internal market, and the free movement of goods, services and capital. The first document on this issue was the Treaty of Mastricht (signed in February 1992, entered into force 1 November 1993), and as a source of the EU law it set priorities for energy policy. The first document concerning the issues associated with the use of renewable energy sources was called the Madrid Declaration, signed in March 1994. In accordance with the provisions of the Declaration, the European countries should have achieved by $2005-10 \%$, and by $2010-15 \%$ of "clean energy" in energy production. The Madrid Declaration became the basis for the subsequent documents on the issue of renewable energy sources prepared by the European Union. The example of such a document was White Papers "Energy for the future: renewable sources of energy", published in March 1997, but its assumptions had been published before in the so-called Green Papers. The White Papers confirmed the European Union assumptions to reach the participation of RES in the energy balance at the amount of $12 \%$ in 2010 . For the EU legislation in the

3 M.S. Szukalski, S.Malinowski, Energia odnawialna Technologia, ekonomia, finansowanie, Poddębice 2013, p. 24. 
field of renewable energy sources there are two important Green Papers: of 2000 and 2006, as well as the White Papers of $1997^{4}$.

In order to achieve the intended objectives, since 1999 the European Union has launched the Implementation Campaign, which outlined the schedule of actions to implement the assumptions of the White Papers.

Currently, the Directive 2009/28/EC of 23 April 2009 on the promotion of energy from renewable sources amending and subsequently repealing Directives 2001/77/EC and 2003/30/EC, has the strategic importance for RES in the EU Member States. This act determines the legal frames of support in the scope of energy from renewable energy sources. As the measures necessary to reduce greenhouse gas emissions, as well as to fulfill provisions of the Kyoto Protocol to the Framework Convention of the United Nations on the climate change, the European Union has set two objectives: the control of energy consumption in Europe, and the use of energy from renewable sources associated with energy savings and increased energy efficiency. The adopted Directive increases energy security, contributes to support the development of innovation and technology, as well as creates employment opportunities and regional development. Another priority provision of the adopted Directive is reduction of greenhouse gas emissions in the European Union and its independence of energy imports. Next objective of the document is the EU obligation to develop renewable energy after 2010. This provides the participation of energy from renewable sources in the total energy consumption at the rate of $20 \%$, and $10 \%$ participation of biofuels in overall consumption of petrol and diesel, which Member States are required to achieve by 2020. In accordance with the provisions agreed upon by the European Parliament, Commission and Council, it is acknowledged as reasonable to establish mandatory targets for individual Member States of the European Union, as to guarantee certainty for the investors in renewable energy sources, as well as to contribute to the development of new technologies that produce energy from natural sources. Considering the individual targets for each country, inter alia, energy potential is taken into account. In case of Poland the aim is to increase the participation of energy from renewable sources in the final gross energy consumption from $7.2 \%$ in 2005 to $15 \%$ in 2020. "Each

D. Niedziółka, Zielona energia w Polsce, Warszawa 2012, p. 19-20.

OJ L 140, 23.04.2009, p. 16. Source: http://www.ure.gov.pl/pl/prawo/prawow spolnotowe/dyrektywy/4925,DzU-UE-L-0914016.html (20.06.2014). 
Member State shall take care that its participation of energy from renewable sources (...) in final gross energy consumption in 2020 is at least its national overall target for the participation of energy from renewable sources this year. (...) Each Member State shall promote efficiency and energy saving and encourage to them. Member States shall introduce measures effectively designed to ensure that the participation of energy from renewable sources is equal to the participation determined in the indicative trajectory set in the state aims". The measures applied by the Member States to achieve these objectives may include support systems, and cooperation between Member States and third countries.

Worth mentioning is the European Union EUROPE 2020 strategy for smart, sustainable economic growth and social inclusion, which covers the period from 2010 to 2020. The main objective outlined in this document is to achieve economic growth while using low-emission economy. One of the assumptions of the European Union in 2020 is to have limited greenhouse gas emissions by $20 \%$ or $30 \%$ under favorable conditions, in comparison with 1990 levels. Secondly, 20\% of energy should come from natural sources. Thirdly, energy efficiency should increase by $20 \%{ }^{7}$.

Four years after the adoption of the Europe 2020 strategy, the European Commission published a communication summarizing past actions. The presented data show that targets for reducing greenhouse gas emissions and increasing the participation of energy from renewable sources are possible to achieve in 2020, and the progress is already visible. Even before 2012 the European Union reduced its greenhouse gas emissions by $18 \%$. According to forecasts, further progress to reduce greenhouse gas emissions in 2020 to $24 \%$ in comparison with 1990 can be expected. In the scope of proportion of energy from renewable sources in 2012, it was $14.4 \%$ compared with $7.5 \%$ in 2000 , which means that the target can be achieved in $2020^{8}$.

The appropriate mechanism and instruments promoting renewable energy sources are associated with the development of effective instruments regulating the production of RES. This is not only to promote building

6 Directive 2009/28/EC, article 3., op.cit.

7 EUROPE 2020. Source: < www.ec.europa.eu> (29.06.2014).

8 Commission's Communication to the European Parliament, the Council, the European Economic and Social Committee and the Committee of the Regions of 5 March 2014, Summary of the strategy "Europe 2020" for smart, sustainable and social inclusive growth. 
plants using natural energy sources, but also to provide investors with longterm incentive to invest in renewable energy, and to modernize the existing infrastructure. In the future, the current system of development and support of renewable energy at EU level can be adapted to changing conditions in the scope of economic development. However, it will constitute an additional task to elaborate on goals and strategies after 2020. In accordance with the Directive 2009/28/EC ${ }^{9}$, the European Commission is obliged to present a strategy for the RES after 2020 by 2018 . However, in order to encourage long-term investments that will give the opportunity for further reduction of greenhouse gas emissions and costs, as well as will increase the participation of RES, the unambiguous direction of the European Union policy after 2020 is needed to be determined. Along with the necessity to reduce the uncertainty of investment.

\section{The current legal status in the field of RES in Poland}

The first regulation on the issue of renewable energy sources was the Minister of Economy Ordinance of 2 February 1999 on the obligation to purchase electricity and heat from unconventional sources, and the scope of this obligation ${ }^{10}$, which was amended a year later. In the result of the amendment (of 1 January 1, 2003 in article 9a of the Energy Law), it was replaced by a new ordinance of the Minister of Economy, Labour and Social Policy of 30 May $2003^{11}$. One of the alternations introduced an obligation to purchase electricity extracted from natural sources by all companies engaged in electricity trading. These companies were also obligated to ensure adequate participation of renewable energy in the sale ${ }^{12}$.

Accession of Poland to the European Union in 2004 created the necessity to adjust state legislation in the field of renewable energy sources to

9 Directive 2009/28/EC, article 3... op. cit.

10 Journal of Laws of 1999, No 13, item 119.

11 Journal of Laws, No 104, item 971.

12 M.S. Szukalski, S. Malinowski, Energia odnawialna..., op. cit., p. 47-48. 
the general principles, in particular to then applicable provisions of the Directive 2001/77/EC ${ }^{13}$.

The most important changes in this area after 2004 were, among others, enabling the sale of property rights to certificates of origin of electricity produced from renewable sources, imposing on companies conducting the sale of electricity to the final recipients the obligation to obtain and present for redemption the so called certificates of origin or to pay a substitute fee. In Poland an important document in the field of renewable energy is the Polish Energy Policy by 2030. This document defines the objectives, including, among others, increasing participation of renewable energy in the global consumption of at least $15 \%$ in 2020 , achieving participation of biofuels at the level of $10 \%$ of participation on the market of transport fuels, and using agricultural land for the purposes of $\mathrm{RES}^{14}$.

On 23 April 2009 the Directive 2009/28/EC on the promotion of energy from renewable sources was adopted, as a consequence of which the previously binding Directives 2001/77/EC and 2003/30/EC became invalid.

The Directive 2009/28/EC should have been implemented into Polish legal system on 5 December 2010 but Poland had only partially complied with this obligation. In fact, legislative efforts to fully transpose the EU regulations have been in progress since then.

The state legal act of fundamental importance in the field of renewable energy sources, which is in accordance withthe Directive 2009/28/EC, is the amended Act of 10 April 1997 on the Energy Law ${ }^{15}$ with the amendments introduced to the act by the so-called "Small-pack energy", adopted by the Parliament on 26 July 2013. "Small-pack energy" includes regulations on investments in renewable energy in Poland, such as the definition of micro-installations and a small installation, the regulations concerning the conditions and fees associated with the connection to the distribution network, the principles of energy production in the micro-installations without obligation to register the business, the guarantees to purchase energy ex officio. The introduced regulation does not concern the issues concerning a support systems of micro- and small-installations of renewable

13 Source: http://www.ure.gov.pl/pl/prawo/prawo-wspolnotowe/dyrektywy/1271,DzUL-283-z-27102001.html (20.06.2014).

14 M.S. Szukalski, S. Malinowski, Energia odnawialna..., op. cit., p. 119.

15 Journal of Laws of 2006, No 89, item 625 with amendments. 
energy sources. However, the implemented changes have not fully adjusted the Polish legal system to the rules imposed on by the Directive 2009/28/EC ${ }^{16}$

Functioning of the support systems for the production of energy from RES is based on issuing certificates of origin, the so called green certificates, and certificates of origin for agricultural biogas, the so called brown certificates. The prices of these property rights are shaped on the basis of the market mechanism, which promotes competition. In addition, the turnover of property rights derived from renewable energy certificates on the stock market is also possible. The documents confirming the generation of electricity from renewable energy sources are "certificates of origin" (article 9e section 1 of the Energy Law). Certificates of origin are issued by the President of the Energy Regulatory Office (ERO). In the article 9a of the Energy Law, the legislature obliges the industrial recipient, the energy company, the final user and the commodity brokers to obtain "certificates of origin" and present them for redemption by the President of the Energy Regulatory Office. This provision provides for the commercial value of the certificates of origin. The indicated obligation may also be fulfilled by paying a substitute fee. The listed prices of "certificates of origin" can be determined on the basis of quotations posted by the Commodity Energy Market. In accordance with article 9a section 2 of the Energy Law, the fee per unit amounts to $240 \mathrm{zt} / \mathrm{MWh}$. The fee is indexed and announced by the President of the ERO until 31 March of each calendar year. The price of the unit substitute fee in 2014, according to information provided by the President of ERO, is $300.03 \mathrm{zl}$ per $1 \mathrm{MWh}$. Another important issue which is regulated by the Energy Law is a statutory obligation to guarantee the sale of energy generated from renewable sources (article 9a section 6 of the Energy Law). The purchase price is held at an average selling price of electricity in the previous year. The solutions presented in the Energy Law promote the development of the so-called prosumer energy - a process that involves the consumption of energy generated from natural sources for one's own need and then selling surplus to electricity networks. In accordance with article $9 \mathrm{u}$ of the Energy Law, conducting micro installations and production of energy, by a natural person who is not a businessman in accordance with the provisions of freedom of business activity, and the sale of this energy,

16 Ibidem.p. 119, 140-141. 
is not a business activity. In addition, article $9 \mathrm{v}$ of the Energy Law introduces the obligation to purchase electricity produced in micro-installations by the vendor operating in the area. According to the definition given by the Energy Law, micro-installation is a renewable source of energy, which installed electric power does not exceed $40 \mathrm{~kW}^{17}$.

\section{Changes in the Polish legal system after entering into force the Act on renewable energy sources}

It should be noticed that at the moment in the Polish legal system there is no single act that would regulate the issues of renewable energy sources. Noteworthy is also the fact that most of the EU countries have already adopted a law that guarantees the development of renewable energy and regulates the legal framework for the activity of plants using RES. For this reason, on 8 April 2014 the Council of Ministers adopted a draft law on renewable energy sources ${ }^{18}$. Works on its final shape are still in progress.

The purpose of the Act on RES is to create legal framework in accordance with the European standards, as well as to implement certain provisions of the Directive 2009/28/EC. The effect of the new law will be an announcement of the objectives for the development of renewable energy sources resulting from government documents (the Polish Energy Policy by 2030 and the State Action Plan in the field of renewable energy). Another important result of the implementation of the act will be unification of the support system that will encourage investments in green energy resources ${ }^{19}$.

The legislature introduces several new instruments which aim is to optimize the oversupply of certificates of origin. Firstly, the bill introduces a restriction on the issuance of certificates of origin of electricity produced in multi-fuel technology. Secondly, the act is to eliminate mechanisms of support for hydroelectric power plants, which power exceeds $5 \mathrm{MW}$, and

17 Justification of the draft law on renewable energy sources of 08.04.2014, source: https://www.premier.gov.pl/wydarzenia/decyzje-rzadu/projekt-ustawy-o-odnawialnychzrodlach-energii.html (26.06.2014).

18 Source: http://bip.kprm.gov.pl/kpr/wykaz/r198,Projekt-ustawy-o-odnawialnychzrodlach-energii.html (28.06.2014).

19 M. Rudnicki, K. Sobieraj, Nowe prawo energetyczne, Lublin 2013, p. $20-21$. 
which, for the first time, produced electricity prior to the entry into force of the bill. Thirdly, another instrument to counter the oversupply of energy certificates will be the lack of possibility to fulfill the obligation by payment of the replacement fee (article 47 of the draft law on renewable energy sources) $)^{20}$.

Among the significant alterations that have been proposed in the new bill, is to change support systems of renewable energy production. In order to meet the European Commission's recommendations, the legislature has introduced a new support system that would be based on auction system. The introduction of the new procedure is to contribute to fulfillment of the obligations imposed on Poland by the European Union in the scope of green energy production in the most cost-effective way. The auction system is to ensure the competitiveness on the RES market. Its consequence will be the development of the most cost-effective installations. Moreover, the auction system is intended to prevent unjustified "oversupport" that appears under the current support system called "green certificates".

Detailed information in terms of quantity and value of energy from renewable energy sources, which will be able to be purchased in an auction, will be determined by the Council of Ministers. While determining the amount and value of the energy national energy policy, the current participation of energy and fuels derived from renewable sources, the security of the power system, as well as the obligations arising from international agreements will be taken into account (article 73 of the draft law on renewable energy sources). At least once a year auctions are to be announced, organized and carried out by the President of the ERO. Extremely important is the fact that at least $25 \%$ of the amount of electricity generated from renewable sources of energy, sold in an auction to producers who have produced electricity for the first time after the close of the auction, "should be produced in the renewable energy installations with a total installed power up to $1 \mathrm{MW}$ of electricity" (article 74 section 6 of the draft law on renewable energy sources). The aim of such a solution is to create the local installations of renewable energy sources, based on the activity of small and mediumsized enterprises. Auctions are to be carried out separately for the installation of renewable energy sources with a total installed power less than $1 \mathrm{MW}$, and those with more than $1 \mathrm{MW}$. Information on the maximum price for

20 Justification of the draft law on renewable energy sources of 08.04.2014. 
$1 \mathrm{MW}$, for which electricity from renewable energy sources can be sold on an auction in a certain year by producers, is determined by the Minister of the Economy 60 days before the first auction in the calendar year (the so-called price reference). The novelty of the draft law, is the appointment of the 15-year period of support, which establishes a period of being subject to support mechanisms for renewable energy or biogas ${ }^{21}$.

New and modernized installations of renewable energy sources are to be covered by the auction system. In the case of existing installations, a 15-year support period shall be counted from the date of producing energy for the first time, for which a certificate of origin is entitled. Furthermore, the provisions that are being introduced enable existing installations covered so far by the system of certificates of origin (installations that for the first time produced energy before the entry into force of the proposed act), to change for the auction system ${ }^{22}$.

\section{Closing remarks}

The increased interest in renewable energy sources, the attractiveness of investing in renewable energy sources in Poland, Polish accession to the European Union and related with that necessity to implement the EU legislation to the Polish legal system, created the need for changes in the scope of energy law and related fields.

In addition to the abovementioned acts, the Act of 25 August 2006 on components and liquid biofuels, should be noted as important in the context of RES in Poland.. Its amendment of 21 March 2014 implements the provisions of the Directive 2009/28/EC on the use and promotion of energy from renewable sources. The act that undoubtedly supports RES is the Act of 27 April 2001 on Environmental Protection Law, which includes funding rules of environment protection by, among others, "support the use of local renewable energy sources". Furthermore, article 91 of this act specifies that in the areas with exceeded levels of substances in the air, 
air protection programs, including the implementation of renewable energy, should be prepared ${ }^{23}$.

The works of the Polish government to fully implement the Directive 2009/28/EC into the state legal system are continuing. Poland only partially fulfilled the obligation. The transposition of the Directive is the need of the moment, not only because of the law stability for investors who want to start the production of energy from renewable sources. It is also to protect our country against the imposition of penalties by the European Union for failure to implement the Directive on time.

It is the instability of the Polish system, in the context of the regulation of a new system of law, that is indicated as the main barrier to investments in renewable energy sources in our country. In addition to the legal barriers, also the administrative barrier, associated mainly with the lengthy procedure of the decision to build and launch the plant, and to obtain all necessary permits, is pointed out. Another aspect is found in social protests, which are dictated by a local community fear for, among others, health, crop safety, decrease in real estate value, noise level, deterioration of the landscape. This situation is mainly due to low social awareness, as well as the lack of information on investors and the local authorities. In order to avoid such situations, further public clarification of the pros and cons presented to the inhabitants by means of public consultations, which can help decrease the number of protests, is needed.

Extremelyimportantinstrumentsthatincreasetheefficiencyofinvestments in renewable energy sources are the founding mechanism, which may take form of grants and loans. Projects related to RES are financed by the EU grants and funds from the Regional Fund for Environmental Protection and Water Management (Regional Fund). Furthermore, on 8 April 2014 the Council of Ministers adopted the Enterprise Development Program by 2020, which also supports investments in renewable energy ${ }^{24}$.

Dynamically growing sector related to renewable energy sources is an opportunity to guarantee energy and economic security of Poland. It is also the way to make our economy independent from fluctuating energy commodity prices, and guarantee stability in this area. Will these aims be achieved? The answer for this question will be known with time.

23 Journal of Laws of 2013, item 1231 with amendments.

24 M.S. Szukalski, S. Malinowski, Energia odnawialna..., op.cit., p. 173. 


\section{Bibliography}

Niedziółka D., Zielona energia w Polsce, Warsaw 2012.

Szukalski M.S., Malinowski S., Energia odnawialna Technologia, ekonomia, finansowanie, Poddębice 2013.

Rudnicki M., Sobieraj K., Nowe prawo energetyczne, Lublin 2013.

\section{Emails}

grzegorz.ignatowicz@kancelariecls.pl

edyta.dolegowska@gmail.com 